Mateusz SALWA

\title{
ESTETYKA, ETYKA I LOGIKA OGRODU. FILOZOFIA ROSARIA ASSUNTA
}

W ostatnich dekadach badania nad ogrodami rozwijają się intensywnie i w wielu kierunkach ${ }^{1}$. I choć, być może, należy się zgodzić z J. Elkinsem $^{2}$, że badaniom tym brakuje ustalonych pojęciowych podstaw takich, jakimi dysponuje np. historia sztuki, co powoduje, że mają one bardziej płynny charakter, to zarazem nie można mieć wątpliwości, że garden studies stały się odrębną dziedziną badawczą, której obszar obejmuje $\mathrm{z}$ jednej strony zagadnienia związane $\mathrm{z}$ analizą i interpretacją projektów oraz zrealizowanych historycznych ogrodów, ich recepcją, a co za tym idzie z kulturowymi praktykami związanymi z ogrodami, z drugiej zaś obejmuje także kwestie restauracji i konserwacji ogrodów, współczesnego ich funkcjonowania oraz ich wartości ekologicznej3.

W taki czy inny sposoby garden studies są zatem zorientowane przede wszystkim historycznie i mimo że nie sposób im odmówić teoretycznej świadomości, to wiąże się ona przede wszystkim ze stosowanymi narzędziami. Refleksja teoretyczna, nazwijmy ją filozoficzną, związana z podstawowym pojęciem, którym w tym wypadku jest ogród, sytuuje się na marginesie badań ogrodowych. Jeśli jednak ogrody są analizowane z filozoficznego punktu widzenia, to przeważnie są traktowane jako wyraz bądź ilustracja określonej filozofii wyznawanej przez ich twórcę bądź

1 Por. J.D. Hunt, On the formation and conduct of garden history, „Rocznik Historii Sztuki”, t. XXXIV, 2009, s. 5-11. W niniejszym artykule wykorzystuję materiały zebrane dzięki grantowi NCN (2011-2014) nr 2011/01/D/HS1/01661.

2 J. Elkins, On the conceptual analysis of garden, „Journal of Garden History”, vol. 13, 1993, nr 4, s. 189.

${ }^{3}$ Por. The History of Garden Design. The Western Tradition form the Renaissance to the Present Day, ed. M. Mosser, G. Teyssot, London 1991; A Cultural History of Gardens, 6 voll., Bloomsbury, London 2013; numer tematyczny „Die Gartenkunst”, Bd. 9, 1997, H. 7; polski dorobek (J. Bogdanowicz, G. Ciołek, L. Majdecki) w tej materii jest też znaczny, przy czym kładzie się w nim nacisk na analizy projektów i ich realizacji. 
środowisko, w którym powstały ${ }^{4}$. Rzadko kiedy ogród jest ujmowany jako problem filozoficzny tout court, niemniej i w tej kwestii koniec XX w. przyniósł zmiany - ogrodem jako rodzajem dzieła sztuki na powrót bowiem zainteresowała się po niemal 200-letniej przerwie estetyka. Z jednej strony estetycy anglosascy próbowali odpowiedzieć na pytania w rodzaju „czym jest ogród?” bądź „w jaki sposób ogród może coś znaczyć?”, z drugiej zaś badacze na Starym Kontynencie analizowali ogród jako „miejsce filozoficzne”, przyjmując przy tym historyczny punkt widzenia ${ }^{5}$.

$\mathrm{Na}$ tym tle pozycję szczególną zajmuje włoski filozof Rosario Assunto, który z ogrodu uczynił jeden z filarów swej refleksji, znacznie wyprzedzając wyżej wspomniane tendencje ${ }^{6}$. Od lat 70 . Assunto uchodził przede wszystkim we włoskim środowisku, choć nie tylko, za filozofa, który dostarcza filozoficznego kontekstu dla zagadnień związanych z ogrodami, zwłaszcza dla kwestii restauracji i konserwacji ogrodów ${ }^{7}$. Ponadto, był

${ }_{4}^{4}$ Por. Zachód. Ogrody - zwierciadła kultury, t. 2, red. L. Sosnowski, A.I. Wójcik, Kraków 2008; Przestrzeń ogrodu, przestrzeń kultury, red. G. Gazda, M. Gołąb, Kraków 2008.

5 Zob. M. Miller, The Garden as an Art, New York 1998 (po polsku dostępny m.in. M. Miller, Ogród jako dzieło sztuki, przeł. A. Burzyńska, (w:) Eidos sztuki, red. M. Gołaszewska, Kraków 1988); S. Ross, What Gardens Mean, Chicago-London 1998; D.A. Cooper, A Philosophy of Gardens, Oxford 2006; Gardening. Philosophy for Everyone, ed. D. O’Brien, Oxford 2010; M.V. Ferriolo, Nel grembo della vita. Le origini dell'idea di giardino, Milano, 1991; Ph. Nys, Le jardin exploré. Une herméneutique du lieu, vol. 1, Besançon 1999; J.-P. Dantec, Poétique des jardins, Arles, 2011.

${ }^{6}$ Rosario Assunto (Caltanissetta, 1915 - Rzym, 1994), w latach 1956-1981 wykładał filozofię na Uniwersytecie w Urbino, później z kolei objął katedrę historii filozofii włoskiej na Uniwersytecie La Sapienza w Rzymie; był członkiem korespondentem wielu włoskich akademii naukowych. Jest autorem kilkudziesięciu książek i kilkuset artykułów, w których zajmuje się rozmaitymi problemami estetycznymi ujmowanymi tak historycznie, jak i teoretycznie. W swych pracach sięga w równym stopniu do estetyki starożytnej, średniowiecznej, nowożytnej, jak i nowoczesnej. Najwięcej jednak uwagi poświęcił estetyce XVIII-wiecznej (m.in. wydał włoskie przekłady pism I. Kanta). Assunto napisał też rozliczne hasła do encyklopedii, z których na szczególną uwagę zasługuje Enciclopedia Universale dell'Arte (1958; wyd. ang. Encyclopaedia of World Art[1959]). Zasiadał w licznych komitetach naukowych, m.in. Centro Internazionale di Studi sull'architettura „Andrea Palladio" w Vicenzy (któremu to centrum przekazał swoją bibliotekę). Był też członkiem komisji i komitetów przy włoskim Ministerstwie Dóbr Kultury i Środowiska zajmujących się ochroną historycznych ogrodów. Ponadto, regularnie pisywał do dzienników i tygodników, stając w obronie wartości ogrodów historycznych i krajobrazów, za co otrzymał nagrodę im. C. Scarpy przyznawaną przez Fundację Benettona.

7 Zob. wydaną przez Komisję Europejską pozycję Historic Gardens. Safeguarding a European Heritage (Bruxelles, 1996), w której znajduje się tekst Assunto (s. 7-18) pt. Philosophy, dający filozoficzne uzasadnienie dla ochrony ogrodów; także R. Assunto, Téléologie des jardins (1987), (w:) Jardins et sites historiques, ICOMOS, Madrid 1993, s. 241-244; zob. także M. Beneš, Recent Developments and Perspectives in the Historiography of Italian Gardens, (w:) Perspective on Garden Histories, ed. M. Conan, Washington D.C. 1999 , s. 53. 
on - również jako publicysta - niezmordowanym szermierzem idei ochrony krajobrazu, której teoretyczne podstawy również formułował, co pozwala nań spojrzeć jako na wczesnego przedstawiciela tzw. estetyki ekologicznej ${ }^{8}$.

Jego poglądy zebrane w dwóch książkach, Ontologia i teleologia ogro$d u$ oraz Krajobraz i estetyk $a^{9}$, należy uznać za najbardziej systematyczną próbę uprawiania „filozofii ogrodu”, tzn. próbę wykazania, że ogród ma znaczenie filozoficzne, a ogrodnictwo to działanie filozoficzne ${ }^{10}$. Ponieważ koncepcje Assunta klarowały się przede wszystkim w latach 70. XX w., przez co odzwierciedlają określony sposób myślenia o kulturze (np. masowej), oraz stanowią reakcję na swoistą sytuację kulturalną Włoch z okresu boomu gospodarczego (skutkującego m.in. budową autostrad i gwałtowną urbanizacją), mogłoby się wydawać, że po półwieczu nieuchronnie musiały stracić na aktualności. Tak jednak nie jest. Wynika to nie tylko z samej koncepcji Assunta, ale także z trafnie postawionej przezeń diagnozy, która sprawdza się również dzisiaj, mimo że zdano sobie sprawę z błędów popełnionych w okresie, do którego się odnosił. Walory jego koncepcji wychodzą również na jaw, gdy zestawi się ją ze współczesnymi filozoficznymi ujęciami problematyki ogrodów. Posługując się odmiennym idiomem, a na dodatek dysponując o wiele większą wrażliwością historyczną, Assunto dochodzi do podobnych wniosków co autorzy współcześni, czy to wtedy, gdy próbują oni określić, czym jest ogród, czy to gdy odnoszą sztukę ogrodową do innych sztuk, czy to wówczas, gdy

${ }^{8}$ P. d'Angelo, Per una critica dell'estetica ecologica, (w:) La natura tra Oriente e Occidente. Atti del Convegno Nazionale dell'Associazione Italiana Studi di Estetica (A.I.S.E.), a cura di R. Troncon, L. Editrice, Milano 1996, s. 119-127.

9 Ontologia e teleologia del giardino, Milano (I wyd.: 1988; II wyd.: 1994; wznowienie: 2009); Il paesaggio e l'estetica, Napoli 1973 (Palermo (I wyd.: 1994, II wyd.: 2005)); omówienie jego poglądów można znaleźć m.in. w: R. Milani, L’arte del paesaggio, il Mulino, Bologna, 2001; M.V. Ferriolo, Transformare in giardino il mondo: Rosario Assunto e l'etica della contemplazione, (w:) Luoghi. Forma e vita di giardini e di paesaggi (Premio Internazionale Carlo Scarpa per il Giardino, 1990-1999), a cura di D. Luciani, Fondazione Benetton Studi Ricerche / Canova, Treviso 2001, s. 58-69; R. Assunto, Retour au jardin. Essais pour une philosophie de la nature, 1976-1987, textes reunis, traduits de l'italien et présentés par H. Brunon, Besançon 2003; myśli Assunta poświęcono także kilka konferencji naukowych, zob.: Rosario Assunto e le estetiche del Novecento. Atti del Convegno nazionale di studi, 24-25 gennaio 2003, a cura di F. Mercadante, P. Zanetov, Palermo (2007); Il giardino: mito estetico di Rosario Assunto, a cura di Marisa Sedita Migliore, Caltanisetta 2000; A Rosario Assunto. In memoriam, Palermo 1995; koncepcją Assunta zająłem się także w: Ogród - przestrzeń między filozofią i natura, (w:) Przestrzenie późnej nowoczesności, red. I. Lorenc, M. Salwa, Łódź 2011, s. 265-275.

${ }^{10}$ R. Assunto, Il giardinaggio come operazione filosofica, (w:) Paradisi ritrovati. Esperienze e proposte per il governo del paesaggio e del giardino, a cura di M. Cunico, D. Luciani, Treviso-Milano 1991, s. 7-12. 
uznają, że ogród to miejsce epifanii ludzkiej egzystencji w naturze, albo wreszcie wtedy, gdy koncentrują się na ekologicznych aspektach ogrodów. Co więcej - i w tym przede wszystkim należy upatrywać znaczenia jego koncepcji - sposób, w jaki Assunto ujmuje zagadnienie powszechnie uznane za konstytutywne dla ogrodu, mianowicie fakt, że w ogrodzie dochodzi do swoistego splotu sztuki i kultury, pod wieloma względami jest najpełniejszy, a zarazem najbardziej otwarty na rozmaite interpretacje.

Trzeba przy tym od razu zaznaczyć, że jego filozofia jest celowo anachroniczna (Assunto niemal nie odwołuje się do panteonu filozofów 2. połowy XX wieku; najchętniej korzysta z dorobku np. M. Horkheimera czy J. Ortegi y Gasseta), czego wyrazem jest jej swoisty esencjalizm czy też język spod znaku niemieckiej filozofii idealistycznej, do której bezustannie się odwołuje (I. Kant, G.W.F. Hegel, G.W. Fichte, F.W.J. Schelling, F. Schiller, A. W. Schlegel). Notabene, zainteresowanie estetyką XVIII wieku, zwłaszcza niemiecką, wypływa u niego również z faktu, że - jak sam zauważa - to nie kto inny, tylko Kant i filozofowie niemieccy nadali ogrodowi wymiar filozoficzny, tzn. uczynili zeń filozoficzny problem, próbując osadzić ogrody w dziedzinie sztuki, a przez to traktując je jako miejsce sprzyjające filozoficznej refleksji nad relacją człowiek / natura ${ }^{11}$.

Ponadto, filozofia ta naznaczona jest romantyczną wizją natury, zaczerpniętą również od niemieckich poetów (F. Hölderlin, R. M. Rilke) i włoskich (G. Leopardi), a przy tym wszystkim stanowi mieszaninę utopijnej wizji świata z praktycznym nastawieniem (Assunto nie stroni od dawania praktycznych rad, w czym zresztą objawia się jego publicystyczne zacięcie).Wyżej wymienione cechy - do których należałoby dodać jeszcze wrażliwość na historyczną materię (Assunto doskonale zna historyczne ogrody i literaturę na ich temat, od traktatów po poezję) - powodują, że dla jego koncepcji trudno znaleźć jakikolwiek odpowiednik, i czynią z niej zjawisko osobne. Z tego względu trudno wskazać inne źródła jego refleksji niż filozofia XVIII i XIX w., zaś jeśli chodzi o myśl wieku XX, to - z nielicznymi wyjątkami - można wskazywać właściwie wyłącznie na paralele.

Mimo walorów proponowanej „filozofii ogrodu” poza granicami Włoch myśl Assunto pozostaje mało znana ${ }^{12}$. Tym bardziej zasługuje więc na to,

11 Kwestia ta została szczegółowo opracowana: M.G. Lee, The German „Mittelweg”: garden theory and philosophy in the time of Kant, New York 2007.

12 Obok wspomnianej (zob. przyp. 9) antologii francuskiej i artykułów w języku angielskim francuskim (zob. przyp. 7), istnieją także przekłady na język rumuński; jeden z tekstów Assunta ukazał się w „Studiach Estetycznych”: Le paysage comme objet esthètique et le raport de l'homme avec la nature, t. 4, 1967, s. 337-349; ostatnio także ukazał się: R. Assunto, Natura jako krajobraz i wolność człowieka, przeł. M. Salwa, (w:) Krajobra- 
by przynajmniej skrótowo zaprezentować jego dorobek polskiemu czytelnikowi. Ponadto, w literaturze polskiej brak też filozoficznych ujęć problematyki ogrodu i nawet jeśli opracowania dotykają zagadnień teoretycznych albo też „poezji” ogrodów (D. Lichaczow), to kwestie te są osadzone albo w kontekście historycznym, albo w kontekście architektury krajobrazu, bardzo rzadko zaś - estetyki jako takiej ${ }^{13}$.

\section{OGRÓD JAKO IDEA}

Swoją filozofię Assunto nazywał estetyzmem spekulatywnym. Miała to być filozofia, która uprawia teorię dla teorii, a nie ze względów praktycznych, ponieważ - zdaniem Assunta - to życie jest ufundowane na myśli, a nie odwrotnie. Dokładniej zaś rzecz ujmując, Assunto badał ideę piękna, widząc w niej ideę nadającą sens rzeczywistości14. Idea estetyzmu spekulatywnego wypływa $\mathrm{z}$ wyżej wymienionych inspiracji filozoficznych, co z kolei tłumaczy predylekcje jej autora do ujmowania relacji sztuka / natura w kategoriach dialektyki, Aufhebung i zapośredniczenia, do opisywania ogrodu jako obiektywizującej się myśli, a zarazem jako zsubiektywizowanej rzeczywistości czy też jako miejsca, w którym Podmiot się uzewnętrznia, a Przedmiot - interioryzuje. Zrozumiała też staje się kantowska w charakterze koncepcja piękna: piękne jest to, co podoba się bezinteresownie i co jest traktowane jako cel sam w sobie. Estetyzm spekulatywny zasadza się także na przekonaniu, że piękno (estetyka) łączy się z prawdą (logiką) i dobrem (etyką), które to przekonanie Assunto przejął z kolei z Najstarszego programu systemu idealizmu niemieckiego. Na czym więc polega ów estetyzm spekulatywny w odniesieniu do ogrodu?

Spekulować filozoficznie na temat ogrodu - pisze Assunto - to szukać odpowiedzi na pytanie „czym jest ogród?”: nie ten czy tamten ogród, ale ogród w swej istocie, ogród pod względem tego, co powoduje, że ogrodem jest każdy ogród, w którym zdarza się nam bywać; może to być ogród malowniczy albo krajobrazowy; ogród zachodni albo ogród wschodni; ogród gotycki, renesansowy bądź barokowy;

zy. Antologia tekstów, red. i oprac. B. Frydryczak, D. Angutek, Poznań 2014, s. 205-213; w przygotowaniu jest także polska antologia jego tekstów (wybór M. Salwa).

13 Por. M. Gołaszewska, Estetyczne przeżycie ogrodu, (w:) eadem, Estetyka możliwości. Eseje filozoficzne, Kraków 2005, s. 195-215.

14 R. Assunto, Ipotesi per un estetismo speculativo (fragm. niepublikowany), cyt. za: M. Pontesilli, Metafisica ed estetica nel pensiero di Rosario Assunto (niepublikowana praca magisterska, 1997/98; promotor: prof. Gennaro Sasso, Università degli Studi di Roma „La Sapienza"), s. 273. 
ogród, w którym rośliny rosną swobodnie bądź ogród, którego wygląd został nadany nożycami posłusznymi ars topiaria ${ }^{15}$.

Definiując zaś ogród, Assunto przyjmuje perspektywę platońską:

Naszym zamiarem jest (...) zaproponowanie ontologii ogrodu. I by pozostać mu wiernym powinniśmy teraz skrótowo zarysować jedną, ogólną ideę Ogrodu, winniśmy naszkicować Teorię Ogrodu, na chwilę abstrahując od praktyki, w której się ona realizuje i ucieleśnia ${ }^{16}$.

Jednym słowem, tym, co interesuje Assunta, jest pojęcie ogrodu, które urzeczywistnia się w ogrodach nie tylko realnych, ale także tych obecnych jedynie na kartach literatury. Szeroko pojęta literatura, którą Assunto zna świetnie - od starożytności po współczesność, od traktatów technicznych po poezję - pozwala, jego zdaniem, zrozumieć istotę ogrodu. Albowiem choć świadectwa literackie odnoszą się często do konkretnych miejsc, chwil i są zapisem jednorazowych doświadczeń określonych osób, to jednak niezmiennie odnoszą się do jednej i tej samej idei ogrodu. Podobnie też jedną i tę samą ideę realizują wszystkie ogrody. Z tego też względu filozof wypowiada się np. przeciwko radykalnemu przeciwstawianiu ogrodów tzw. francuskich ogrodom tzw. angielskim - choć różnią się one stylistycznie i są wyrazem rozmaitych wizji przyrody, świata, interesów itd., to zarazem odnoszą się do jednej i tej samej idei17.

Idea ogrodu, o której tu mowa, musi - zdaniem Assunta - przyświecać zarówno twórcom ogrodów, ich użytkownikom, jak również ludziom doglądającym ich. W innym razie, jak podkreśla, dane miejsce nie jest traktowane jako ogród, ale np. jako „przestrzeń zielona”. Innymi słowy, Assunta interesuje to, co można by nazwać warunkami „bycia ogrodem” zarówno od strony „bytowej”, jak i „poznawczej”.

Taka platonizująca koncepcja, siłą rzeczy, ma charakter esencjalistyczny. Choć idea ogrodu (będąca dla Assunta swego rodzaju kulturowym powszechnikiem, tzn. mająca charakter transhistoryczny i transkulturowy) jest po platońsku niezmienna, to zarazem uzyskuje rozmaite historyczne wcielenia, ponieważ każda epoka wypracowuje własną poetykę:

Owe poetyki zaś to schematyzacje - ośmieliłbym się nawet nazwać je transcendentalnymi - w ramach których idea ogrodu, teoria, dopasowuje się do różnych

15 R. Assunto, Filosofia del giardino e filosofia nel giardino, (w:) idem, Filosofia del giardino e filosofia nel giardino, Roma 1981, s. 14; wszystkie fragmenty podaję w tłumaczeniu własnym - M. S.

${ }^{16}$ Idem, Ontologia e teleologia del giardino, Milano 1994, s. 28.

${ }_{17}$ Notabene, dostarcza także ściśle historycznych argumentów przeciwko takiemu przeciwstawieniu. 
okoliczności historyczno-kulturowych; te zaś w ramach owych poetyk ogrodów dopasowują się do idei urzeczywistnionych w tych poetykach ${ }^{18}$.

Poetyki ogrodów to zatem schematy pośredniczące między ideą ogrodu a rzeczywistymi ogrodami, to ogólne ramy - wyznaczone tyleż gustem, co ideą natury - określające, czym ma być ogród, tzn. jak ma wyglądać i jak należy go doświadczać i interpretować:

Możemy więc - pisze - uznać poetyki za pośredników między bytem a egzystencją, ideą a rzeczywistością - między Ogrodem w samym sobie i dla siebie samego a, powiedzmy, ogrodem Boboli, ogrodem w Casercie albo w Blenheim, stanowiącymi praktyczne jego realizacje, w których Idea urzeczywistnia się dopasowując się do realiów czasów, miejsc i kultur za pośrednictwem poetyki - odpowiednio ogrodu manierystycznego, barokowego i angielskiego ${ }^{19}$.

W podobny też sposób Assunto pojmuje krajobraz, którego wcieleniem jest, jego zdaniem, właśnie ogród. To bowiem, co go interesuje w Krajobrazie i estetyce, to nie tyle konkretne krajobrazy - choć to ich dobro leży mu na sercu - lecz „krajobraz, który - nieco na wyrost - można nazwać transcendentalnym; chodzi tu o ideę krajobrazu leżącą u podstaw wszelkiego możliwego doświadczenia rzeczywistego krajobrazu"20.

Swoistości ogrodu, wyznaczającej zarazem jego istotę, upatruje on w fakcie, że w jego granicach zawiązuje się szczególna relacja między człowiekiem i naturą. Owa relacja ma w pierwszym rzędzie charakter estetyczny, w drugiej kolejności (choć o kolejności można tu mówić jedynie $\mathrm{w}$ sensie logicznym) relacja ta ma charakter etyczny. Relację tę Assunto opisuje zaś językiem zaczerpniętym od (neo)platoników i Kanta: w ogrodzie człowiek bezinteresownie kontempluje naturę i traktuje ją jak cel sam w sobie; w podobny też sposób odnosi się tam do innych ludzi. Ogród zatem to miejsce, w którym dochodzi do pojednania z naturą, do ustanowienia „szczęśliwego związku” z nią, a mówiąc inaczej, do odzyskania raju utraconego. To jedynie w ogrodzie człowiek odzyskuje swoją pełnię i może urzeczywistniać swoje człowieczeństwo zarówno względem innych, jak i względem siebie samego i przyrody. Rzecz jasna, zgodnie z tym, co zostało zaznaczone wyżej, owa estetyczno-etyczna relacja człowiek / natura przybiera rozmaite historyczne wcielenia. Niemniej, jej istota pozostaje niezmienna.

Można w tym miejscu uczynić dwie uwagi. Po pierwsze, Assunto wydobywa na jaw i próbuje uporać się z założeniem, które milcząco przyjmują badacze ogrodów. Uprawianie historii ogrodów jest bowiem możliwe

\footnotetext{
${ }_{18}$ Assunto, Ontologia e teleologia ..., s. 27.

19 Loc. cit.

20 Idem, Il paesaggio e l'estetica, Palermo 2005, s. 20.
} 
tylko wtedy, gdy założy się, że kolejne ogrody i teorie ogrodnictwa można ze sobą jakoś powiązać, ponieważ łączy je coś więcej aniżeli tylko nomenklatura odnosząca się do kolejnych realizacji. Ów wspólny element, ów - by tak rzec - wspólny mianownik (czyli to, co Assunto nazywa „idea Ogrodu") znajduje wyraz w rozmaitych przyjmowanych definicjach ogrodów, które - podobnie jak ujęcie włoskiego filozofa - mają być na tyle wąskie, by pozwolić wyodrębnić pewne miejsca qua ogrody, a z drugiej - na tyle szerokie, by uwzględniać ich różnorodność. Innymi słowy, to właśnie fakt, że różnorodna historyczna treść - tak rozmaita, że skłania niektórych do twierdzenia, że ogrodu nie da się zdefiniować, tzn. nie da się uchwycić jego istotny, i że co najwyżej można mówić o Wittgensteinowskim podobieństwie łączącym poszczególne realizacje - jest zawsze ujmowana w te same ramy, pozwala mówić o historii ogrodów, co dla Assunta oznacza: historii realizacji pojęcia ogrodu. Po drugie, myśl Assunta, że do istoty ogrodu należy szczególny splot sztuki i natury, owocujący „rajskim” otoczeniem, nie odbiega od powszechnie podzielanego przekonania, ugruntowanego przeważnie w historycznych tekstach i ikonografii, tyle że zostaje ona wyrażona językiem filozofii platońsko-kantowskiej.

\section{LOGIKA OGRODU}

Wprost nawiązując do tradycji filozofii idealistycznej, autor Ontologii i teleologii ogrodu stwierdza:

Prawdą zawartą w pięknie ogrodu jest to, że jest on obrazem, który jest zarazem naturą i myślą: naturą jako obrazem myśli i myślą jako obrazem natury. W tej identyczności natury i myśli, jaką jest ogród, życie, rozkoszujące się ogrodem jako naturą ukształtowaną przez sztukę (kolorami, światłami, zapachami, śpiewem ptaków, melodyjnym pluskiem fontann i potężnym hukiem kaskad) utożsamia się z myślą, przez sztukę wytworzoną jako obraz, w swym wiecznym trwaniu nietknięty nieodwracalnym upływem dni i lat. Jest to trwały obraz, w którym nabierają nieskończonego wymiaru kształty natury, uwolnione od przemijalności, która jest konstytutywna dla ich zmysłowej materialności ${ }^{21}$.

Ogród jest zatem miejscem, w którym to, co idealne, utożsamia się z tym, co realne (subiektywność się obiektywizuje, obiektywność się subiektywizuje). Jest to bowiem dzieło, u którego podstawy leży określona idea natury (rzeczywistości), która to idea zostaje zrealizowana w rzeczywistości (naturze). Ogrody zatem stanowią urzeczywistnienie idealnej natury:

${ }^{21}$ Idem, Filosofia del giardino..., s. 29. 
Przez ogrodnictwo możemy i winniśmy rozumieć wyłącznie sztukę sztucznego tworzenia krajobrazu naturalnego, w którym zbiegają się wszystkie uroki natury, takie, jakimi widzi je dana kultura czy cywilizacja ${ }^{22}$.

Idea, myśl jest niezmienna i nieprzemijalna, natomiast rzeczywistość natura, która jest kształtowana tak, by jej odpowiadała - jest zmienna i przemijalna. W ogrodzie dochodzi zatem do napięcia między trwaniem (zagwarantowanym koncepcją ogrodu, tj. zamysłem, projektem) i przemijaniem, między nieskończonością i skończonością (wynikającą z nietrwałej biologicznej materii). Oto jeden z głównych motywów myśli Assunta, który, istotnie, pozwala w nim widzieć filozofa ujmującego w teoretyczne ramy jeden z głównych problemów związanych z zagadnieniami restauracji i konserwacji ogrodów: jak restaurować dzieła, których trwałym „elementem” jest jedynie projekt? ${ }^{23}$ Kształt owej relacji między trwaniem i zmiennością jest także czynnikiem, który wyznacza dwie odmienne poetyki ogrodów:

Ogród - pisze - wytwarza jedność istnienia i następstwa zgodnie z dwiema odmiennymi poetykami. Jedna to poetyka naturalistyczna (malownicza, krajobrazowa) - następowanie po sobie co i raz powracających pór roku wraz ze zmianami, które owo następowanie za sobą pociąga w wyglądach natury, to następstwo jako obraz istnienia; druga poetyka to poetyka ogrodu architektonicznego (plastycznego): zimozielone rośliny, partery, cisowe żywopłoty przedstawiają z kolei następstwo $\mathrm{w}$ istnieniu, które wiecznie pozostaje takie samo; one same nie zmieniają się, zmienia się jedynie światło, które wraz z upływem miesięcy, raz ożywia a raz tłumi ich odcienie i barwy ${ }^{24}$.

Ogrody krajobrazowe ukazują zatem naturę jako zmienną, lecz w swej zmienności niezmienną, tymczasem ogrody architektoniczne ukazują na-

${ }_{22}^{2}$ Idem, Il paesaggio come oggetto estetico e la relazione dell'uomo con la natura, (w:) La natura tra Oriente e Occidente, s. 18-19.

${ }^{23}$ We Włoszech wywiązała się duża debata związana z uchwaleniem Karty Florenckiej (1981); sprzeciw włoskich historyków i konserwatorów wzbudziło m.in. niedocenienie roli natury w ogrodzie przez specjalistów francuskich i koncepcja autentyczności ogrodu, pomijająca aspekt trwania ogrodu w czasie; na ten temat zob.: Tutela dei giardini storici. Bilanci e prospettive, a cura di V. Cazzato, (Ministero per i Beni Culturali e Ambientali, Ufficio Studi), Roma 1989 (wprowadzenie: R. Assunto); Giardini storici. A 25 anni dalle Carte di Firenze: esperienze e prospettive, a cura di L.S. Pelisetti, L. Scazzosi, Milano 2009; notabene jest to problematyka niemal nieporuszana w polskiej literaturze przedmiotu (np. L. Majdecki, Ochrona i konserwacja zabytkowych założeń ogrodowych, Warszawa 1993; D. Sikora, Konserwacja ogrodów regularnych XVII i XVIII w., Warszawa SGGW, 2011); zajmuje się nią za to M. Szafrańska, $O$ zwiazkach teorii konserwacji ogrodów z pewnymi myślami naszych czasow, (w:) Hortus vitae. Księga pamiątkowa dedykowana Andrzejowi Michałowskiemu, red. M. Arszyński et al., Warszawa 2001, s. 263-266 (notabene Szafrańska przywołuje Assunta).

${ }^{24}$ Assunto, Filosofia del giardino, s. 31. 
turę jako niezmienną mimo zachodzących w niej zmian. Te dwie poetyki ogrodowe wyrażają zatem dwie odmienne filozofie natury, zarazem jednak stanowią wyraz dwóch odmiennych filozofii sztuki:

Jest to sztuka, która raz jest interpretowana i wychwalana jako wolność $w$ naturze, wolność nakładająca prawa na naturę (ogród francuski, architektoniczny), a raz jest utożsamiana $\mathrm{z}$ ideałem piękna jako wolności natury, z obrazem naturalnej spontaniczności, nawet jeśli obraz ten otrzymuje się dzięki sztuce ${ }^{25}$.

Ogród to zatem - jak stwierdza Assunto - filozofia natury-jako-sztuki i filozofia sztuki-jako-natury. Z jednej strony, mamy do czynienia z filozofią sztuki, wydobywającą niezmienność, ponadczasowość natury, z drugiej - z filozofią sztuki, która wydobywa dynamiczność życia natury.

Tym samym, dochodzimy do fundamentalnej definicji ogrodu proponowanej przez Assunta: ogród to sztuka jako natura i natura jako sztuka (natura come arte e arte come natura). Definicja ta odnosi się w takim samym stopniu do ogrodów architektonicznych, co krajobrazowych - każdy ogród jest wytworem sztuki i każdy zawiera naturę. W każdym też dochodzi do napięcia między trwaniem, nieskończoną obecnością a przemijaniem, chwilowością, tj. obecnością skończoną. W każdym też właśnie wskutek napięcia między trwaniem a efemerycznością nieskończoność wnika w skończoność, przez co nadaje skończoności nieskończony wymiar, co z kolei każe myśleć o ogrodach jako metaprzestrzeniach.

\section{ESTETYKA OGRODU}

Dla Assunta ogród „to przestrzeń absolutnie inna od przestrzeni, które nasza codzienność konsumuje, konsumując w nich sama siebie"26. Owa odmienność powoduje, że ogród - podobnie jak krajobraz - Assunto wiąże z ideą metaprzestrzeni. Chodzi zatem tu o przestrzeń, której przysługuje pewien naddatek wynikający z faktu, że nie jest ona wyłącznie czystą rozciągłością, którą można zmierzyć i wyrazić ilościowo, lecz jest także uposażona jakościowo 27 . Ów jakościowy wymiar Assunto wiąże przede wszystkim z faktem, że w ogrodach objawia się nieskończoność pod po-

${ }^{25}$ Idem, La natura esteticamente dialetizzata, (w:) idem, Il parterre e $i$ ghiaccai, Palermo 1984, s. 78.

${ }^{26}$ Assunto, Ontologia e teleologia..., s. 23; można zauważyć tu pewne podobieństwo do koncepcji heterotopii Michela Foucaulta (H. Brunon, Avant-propos, (w:) Retour au jardin..., s. 24).

${ }^{27}$ Można się zastanowić, czy w takim układzie koncepcja metaprzestrzeni nie odpowiada koncepcji miejsca, rozmaicie formułowanej na gruncie fenomenologii czy geografii humanistycznej. 
stacią (nie)zmiennej natury. W tym sensie ogrody są dla niego rezerwatami nieskończoności, zaś ich niszczenie - którego był świadkiem i któremu tak gorąco się przeciwstawiał - stanowi ostateczny wyraz współczesnej tragedii kultury, która wraz z industrializacją całkowicie pogrążyła się w czysto ilościowej skończoności. Świat przemysłowy nie jest też zdolny tworzyć ogrodów, co najwyżej jest w stanie wyznaczać „zielone przestrzenie"28. Dla Assunta, mimo pozornego podobieństwa do ogrodów zielone przestrzenie jako ze swej istoty sprowadzone wyłącznie do wymiaru utylitarnego nie mają jednak charakteru jakościowego. Można to dobrze zaobserwować na przykładzie zieleni (natury) obecnej tak w ogrodach, jak i przestrzeniach zielonych:

W słowie wirydarz odniesienie do koloru i do całego jego bagażu symbolicznych znaczeń (...) nie było przymiotnikowym określeniem, nad którym by dominowała mierzalność, a zatem ilościowość właściwa rzeczownikowi (przestrzeni), lecz należało do samego rzeczownika, wskutek czego tym, co się liczyło, była zieloność, a nie geometryczne pojęcie przestrzeni. Kiedy mowa o przestrzeni zielonej, przeciwnie, jakość (zieleń) jest atrybutem powierzchni ilościowo policzalnej, tj. przestrzeni. Wskutek potraktowania jakości jako atrybutu tego, co ilościowe, podkreśla się utylitarystyczny wymiar natury i jej stosunku do człowieka ${ }^{29}$.

Zarazem jednak, jak zauważa Assunto, ogrody mają wszystkie cechy przestrzeni zielonych - jako metaprzestrzenie są przestrzeniami - tzn. mogą np. służyć zdrowiu i ekologii, ale zarazem zawierają w sobie coś więcej, coś, co wynosi je na wyższy poziom. Owym naddatkiem jest, rzecz jasna, piękno (dodajmy: piękno rozmaicie pojmowane i krystalizujące się w formach renesansowych, barokowych, romantycznych itd.). Piękno ogrodów, stanowiące dla Assunto ich immanentny składnik, powoduje z kolei, że właściwą postawą względem nich jest postawa kontemplacyjna:

(...) o ile ogrodem rozkoszujemy się jako dziełem sztuki, tzn. rozkoszujemy się nim pogrążeni w żyjącej kontemplacji, która może mieć jednak charakter działania, o tyle powinniśmy go osądzać wedle kategorii piękna, tj. jako coś, co jest celem samym w sobie, a nie osądzać go wedle norm zinstrumentalizowanej użyteczności. Z tą ostatnią zaś chciałaby wiązać ogrody terminologia urbanistów i zarządców miast, którzy w ostatnich dziesięcioleciach sprowadzili ogrody do rangi punktów zieleni, obszarów zielonych czy zielonych przestrzeni. Miejsca te nie są przeznaczone do kontemplacji, lecz do tzw. spędzania wolnego czasu. Bywa też, że ich istnienie uzasadnione jest jedynie pobudkami higieniczno-ekologicznymi ${ }^{30}$.

28 Assunto nie jest odosobniony w takim pojmowanie terenów zielonych, por. D. le Dantec, J.-P. le Dantec, Le roman des jardins de France. Leur histoire, Paris 1998.

${ }^{29}$ Assunto, Ontologia e teleologia..., s. 109.

${ }^{30}$ Idem, Il giardino come filosofia della natura e della storia, (w:) Il giardino come labirinto della storia, Palermo 1984, s. 11. 
Choć Assunto w tradycyjny sposób łączy piękno i bezinteresowną kontemplację, to zarazem związaną z nimi estetyczność ogrodów opisuje w taki sposób, że wychodzi z XVIII-wiecznego cienia.

(...) ogród - pisze bowiem - który jest miejscem absolutnie innym, odmiennym od otaczających go przestrzeni, jest miejscem, gdzie kontemplowanie faktu, że żyje się w nim i przeżywa go, wynosi nas ponad przygodną i prozaiczną codziennośćcis.

O jakości ogrodów (metaprzestrzeni) będących tym w stosunku do przestrzeni, czym poezja jest wobec prozy, stanowi więc ich - zapożyczając termin od Jana Mukařovskiego - funkcja estetyczna ${ }^{32}$. Mówiąc inaczej, w ogrodzie zmienia się stosunek człowieka do przyrody. Nie chodzi jednak o to, że z praktycznego staje się on teoretyczny, jakby mógł sugerować używany przez Assunta termin kontemplacja, ale o to, że do wymiaru praktycznego (utylitarnego), który nazywa on też po prostu funkcją, dochodzi wymiar estetyczny (reprezentacyjność, według terminologii Assunta), tzn. estetycznej przyjemności zaczyna dostarczać to, z czego w ogrodzie się korzysta ${ }^{33}$. Notabene, zdaniem Assunta (w czym pozostaje wierny nowożytnym teoretykom), ogrodnictwo stanowi kulminację rozmaitych technik rolnych (i architektonicznych), w ramach której zmieniają one charakter w tym znaczeniu, że zyskują walor estetyczny. W tym sensie ogród jest przedłużeniem rolnictwa, a zarazem jest czymś innym, chciałoby się powiedzieć, że jest metarolnictwem, co - jak zobaczymy nie pozostaje bez związku z przeświadczeniem Assunta o ekologicznym wymiarze ogrodów. W ogrodzie zatem na pierwszy plan wychodzi piękno natury, nie tylko natury dzikiej (jak w ogrodach krajobrazowych), ale także natury uprawianej na tradycyjnej wsi, w której funkcja nie zdominowała jeszcze przyrody, przez co ta zachowała swoją estetyczność (ekspresyjność). W krajobrazie rolniczym estetyczność (obecna in potentia) nie ma charakteru niezależnego, jaki uzyskuje dzięki ogrodnictwu, wyrastającemu właśnie z rolnictwa. W ogrodzie widoczna staje się więc zwykle „przezroczysta” estetyczność rzeczywistości ${ }^{34}$. Zarazem jednak,

31 Assunto, Filosofia del giardino..., s. 27.

32 J. Mukařovsky, Estetyczna funkcja, norma i wartość jako fakty społeczne, przeł. J. Baluch, (w:) idem, Wśród znaków i struktur. Wybór szkiców, wybór, redakcja i słowo wstępne J. Sławiński, Warszawa 1970, s. 59-60.

33 Jest to interesujący rys myśli Assunta, pokazujący, w jaki sposób przekracza on tradycję kantowską, co go odróżnia np. od Joachima Rittera, którego tekst Krajobraz. $O$ postawie estetycznej $w$ społeczeństwie nowoczesnym Assunto analizuje w książce Krajobraz i estetyka (zob. przyp. 9).

${ }^{34}$ Gdyby szukać współczesnych paraleli dla tej koncepcji, można by wskazać estetykę codzienności (aesthetics of everyday) (np. Y. Saito, Everyday aesthetics, Oxford-New York 2007). 
w ogrodach funkcja estetyczna dominuje, tzn. względy praktyczne schodzą na dalszy plan. Pod tym względem architektura krajobrazu różni się od „zwykłej” architektury, w której wymiar estetyczny jedynie towarzyszy funkcji. Zatem, nawet jeśli rośliny w ogrodzie mogą być i są użyteczne, to ich wartość wypływa nie z ich użyteczności, lecz z ich piękna. Jeśli więc rośliny w ogrodzie mogą np. dawać owoce, a przez to mogą pełnić taką samą funkcję, jaką pełnią poza ogrodem, to zarazem uprawia się je ze względu na ich piękno (reprezentacyjność), a nie na produkcję i konsumpcję (funkcję). W tym znaczeniu piękno w ogrodzie wchłania użyteczność, czy też - jak pisze Assunto - znosi ją w sensie heglowskiego Aufhebung.

Ogród jest więc miejscem „żyjącej kontemplacji”, w którym natura zostaje przemieniona $\mathrm{w}$ przedmiot kontemplacji, tzn. $\mathrm{w}$ naturę będącą celem samym w sobie. Ponadto, człowiek kontemplując naturę zarazem kontempluje samego siebie w akcie kontemplacji. W tym sensie przemianie ulega również człowiek, który z podmiotu wykorzystującego przedmiot niezależny od niego, a przez to przedmiot, w stosunku do którego nie ma żadnych zobowiązań, przeistacza się $\mathrm{w}$ podmiot rozpoznający się $\mathrm{w}$ naturze, tzn. w podmiot, który rozpoznaje w sobie naturę jako cel sam $\mathrm{w}$ sobie, a przez to rozpoznaje siebie w zewnętrznej wobec siebie naturze, dzięki czemu zaczyna odczuwać z nią więź.

Kontemplacji, o której pisze Assunto, nie należy jednak rozumieć w wąskim sensie, ponieważ - jak zaznacza - może mieć ona charakter działania. Tak więc kontemplowanie ogrodu to nie tylko oglądanie go $\mathrm{z}$ dystansu, lecz wszelkie działanie, od spacerowania po uprawę roślin (Assunto kładzie bardzo silny nacisk na polisensoryczność oraz na to, że przebywanie $\mathrm{w}$ ogrodzie to życie $\mathrm{w}$ ogrodzie, czyli inaczej mówiąc, bycie zanurzonym $\mathrm{w}$ nim). Ludzkie działanie $\mathrm{w}$ ogrodzie nie różni się zatem co do swej istoty od działań podejmowanych przez człowieka poza nim. Różnica między nimi ma charakter jakościowy, gdyż w ogrodzie działanie nabiera charakteru estetycznego i wywołuje poczucie „zadowolenia $\mathrm{z}$ istnienia" 35 .

\section{ETYKA OGRODU}

Zmiana postawy człowieka względem otaczającej go natury, natury w sobie i w innych ludziach, o której dotąd była mowa w kontekście estetyki, wpisuje również ogrody w obszar etyki. Dla Assunto etyka ogrodu

35 Assunto, Ontologia e teleologia..., s. 127; nie sposób nie dostrzec tu podobieństwa do propozycji estetyki „zaangażowania” Arnolda Berleanta, który doświadczenie estetyczne pojmuje jako osiągnięcie swoistej pełni i zaspokojenia, zob. A. Berleant, Aesthetic Function, (w:) Phenomenology and Natural Existence, ed. D.M. Riepe, New York 1973, s. 183-93. 
zasadza się na jego jednostkowości - każdy ogród jest niepowtarzalny, ponieważ znajduje się $\mathrm{w}$ niepowtarzalnym krajobrazie i składa się z niepowtarzalnych ,jednostek". Inspiracją dla rozważań o niepowtarzalności, indywidualności, jednostkowości ogrodów jest dla Assunto wydarzenie, które miało miejsce w ogrodzie i którego głównym bohaterem był Gottfried Wilhelm Leibniz:

Pewnego sierpniowego dnia $1695 \mathrm{r}$. w alejach niewiele wcześniej ukończonego ogrodu zamkowego w Herrenhausen, rezydencji elektorów hanowerskich (ogród był dziełem francuskiego ogrodnika Charbonniera, ucznia Le Nôtre’a) alejami ogrodowymi przechadzała się elektorowa Zofia Charlotta, której towarzyszyli radca dworu Alvensleben oraz Gottfried Wilhelm Leibniz. Filozof wykładał pewne zagadnienie obecne $\mathrm{w}$ jego filozofii, które $\mathrm{z}$ czasem miał podjąć romantyzm (a wcześniej Kant), polemizując $\mathrm{z}$ matematyzującym racjonalizmem. Chodziło o nieredukowalną wielość jednostkowych bytów, z których żaden nie jest taki sam jak inne, tak jak na żadnej roślinie nie rosną dwa liście, które byłyby pod każdym względem identyczne ( $w$ tej kwestii Leibniz rzucił wyzwanie Alvenslebenowi, który - po tym, jak sprawdził, że tak właśnie jest - musiał uznać swoją porażkę $)^{36}$.

Każdy ogród jest zatem niepowtarzalną monadą złożoną $\mathrm{z}$ innych niepowtarzalnych monad, różniących się od siebie jakościowo. W rezultacie, nie ma mowy o traktowaniu ich jak jednostek wchodzących w skład niezróżnicowanej masy, tak jak - zdaniem Assunta - traktuje się przestrzenie zielone i to, z czego się one składają. Owa jednostkowość ogrodów i ich elementów powoduje też, że cechują się one indywidualną wolnością - każda jest celem samym w sobie. Oto na jakiej zasadzie za sprawą człowieka natura, nieprzestająca być naturą, tzn. wciąż podlegająca prawom przyczynowym, zostaje wyniesiona do sfery wolności. Nie oznacza to bynajmniej anarchii, wręcz przeciwnie:

(...) z etycznego punktu ogród jawi się jako miejsce wolności. Jest tak dlatego, że w ogrodzie złożoność i rozmaitość drzew, roślin, kwiatów, elementów rzeźbiarskich, hydraulicznych, architektonicznych zostaje dowartościowana przez nadawanie im formy, czyli działanie, które nie pomniejszając szczególności żadnej z tych złożonych całości, a wręcz przeciwnie - podkreślając ją, harmonizuje ze sobą w jedności totalnej formy wiele odmiennych od siebie jednostek składających się na ową całość [ogród] ${ }^{37}$.

Tak więc, zakładanie i uprawianie ogrodów, a także właściwe życie w ogrodzie ma, dla włoskiego filozofa, wymiar etyczny, wynikający z samej idei ogrodu (co skądinąd także odpowiada długiej tradycji myślenia

\footnotetext{
${ }^{36}$ Assunto, Natura esteticamente dialetizzata, s. 63.

37 Idem, Filosofia del giardino..., s. 22.
} 
o ogrodach, idącej w parze z toposem ogrodu jako raju). Ogród jako taki stanowi zatem miejsce, w którym realizuje się projekt bez mała polityczny:

Za sprawą kontemplacyjnej rozkoszy, jaką daje [to] miejsce, dzięki poczuciu jego piękna, wolność, do której wychowuje ogród, to wolność każdego człowieka pojęta jako warunek i granica wolności wszystkich ludzi. Z tej racji ogród promuje prawdziwą demokrację, demokrację jednostek zasadzającą się na kantowskim imperatywie, nakazującym traktowanie człowieczeństwa w nas samych i w innych jako cel, a nie jako środek i postępowanie według takiej zasady, która powinna stać się powszechnym prawem natury ${ }^{38}$.

Ogród zatem oferuje model szczególnej wolności - wolności jednostkowej, dla której w umasowionym świecie nie ma miejsca. Widać to, zdaniem Assunta, na przykładzie kultury masowej i jej rozrywek, ale także na przykładzie masowej hodowli zwierząt, które pozbawione są swej indywidualności, przez co są denaturalizowane i zamieniane w maszyny produkujące substancje potrzebne konsumentom. Ogród, sytuujący się na antypodach konsumpcji, stanowi miejsce, w którym człowiek masowy może odebrać estetyczne wychowanie, dzięki czemu „pogłębi swoją kulturę, udoskonali odczuwanie, myślenie, powściągliwość”:

(...) ogród to cel i środek zarazem tego, co Schiller (który był m.in. teoretykiem ogrodnictwa jako sztuki) nazwał estetycznym wychowaniem, które daje wolność za pomoca wolności. Rzecz jasna, nie jest to wolność wyzwalająca, o jakiej myślą ci, którzy uważają, że ludzie odwiedzający ogrody mogą zachowywać się, jak im się żywnie podoba, nie mając względów dla innych ${ }^{39}$.

Oto kolejna różnica dzieląca ogrody od przestrzeni zielonych.

\section{OGRÓD I EKOLOGIA}

Bezinteresowna postawa i traktowanie natury jako celu samego w sobie, wyznaczające etyczny stosunek do natury, to nic innego, jak tylko pozostawanie $\mathrm{w}$ zgodzie $\mathrm{z}$ naturą. W ogrodzie zatem człowiek ani nie podlega przyrodzie (człowiek jest istotą wolną, żyje w świecie celów, nieograniczony do świata przyrodniczej konieczności), ani nad nią nie dominuje, arbitralnie podporządkowując ją swym celom. Assunto niejednokrotnie przy tym zaznacza, że stawką w ogrodzie jest wolność człowieka - pod każdym względem jego filozofia ogrodu ma charakter antropocentryczny - ale nie jest to wolność od natury, lecz wolność $w$ naturze, której

\footnotetext{
38 Idem, Ontologia e teleologia..., s. 38.

${ }^{39}$ Loc. cit.
} 
również gwarantuje się wolność w tym sensie, że pozwala jej się funkcjonować zgodnie z jej własnymi prawami. To właśnie do tego rodzaju wolności należy dążyć wszędzie, próbując przekształcić świat w ogród, przezwyciężając stechnicyzowaną wizję świata wcielającą ideał wolności od natury. Warto przy tym zauważyć, że - biorąc pod uwagę etyczny wymiar ogrodu - owa przemiana miałaby również charakter polityczny. Tymczasem jednak, jak pisze:

Dramat niszczenia ogrodów to dramat naszej kondycji, czyli kondycji ludzi bez nadziei (pomyślmy o zniszczonych lasach tropikalnych), skazanych na życie w świecie, w którym nie będzie już ani łąk ani lasów, w świecie pełnym fetoru, ogłuszającym i najeżonym fabrykami i rafineriami ${ }^{40}$.

Mamy zatem do czynienia z tym, co wypada nazwać ekologiczną katastrofą41. Rzeczywistość człowieka przypomina Dantejskie piekło (jak zauważa Assunto, u Dantego piekło ma kolorystykę zdegradowanego środowiska), jednak człowiek może - niczym narrator w Boskiej komedii - powrócić do rajskiego ogrodu, tj. „odzyskać naturę jako ontologiczny horyzont, w którym życie staje się żyjącą myślą, a myśl - myślącym życiem" 42 .

$\mathrm{Z}$ tej racji ogrody - w tym również ogrody historyczne - jako miejsca, w których człowiek bezinteresownie podchodzi do przyrody, wynosząc ją do sfery wolności, w której jest ona celem samym w sobie (choć zarazem jak pamiętamy - nie przestaje być sobą, ponieważ wciąż podlega mechanicznym, przyrodniczym koniecznościom, a przez to może praktycznie służyć człowiekowi), okazują się wzorcowe dla ekologicznego myślenia o rzeczywistości. W ostatecznym rozrachunku, jeśli pominiemy kwestie historyczne, z dzisiejszej perspektywy ogrody jawią się w oczach Assunto jako wcielenia ekologicznego ideału natury, który ma korzenie romantyczne, ale poza tym jest na wskroś nowoczesny. Pod tym względem, koncepcja Assunta zbliżona jest do koncepcji Gernota Böhme'a, który - co prawda jedynie w odniesieniu do ogrodów angielskich - pisze (za Ernstem Blochem) o ogrodnictwie jako technice przymierza między człowiekiem i naturą ${ }^{43}$.

40 R. Assunto, Il restauro dell'idea di giardino e l'armonia dell'uomo e della natura, (w:) Restauració de jardins històrics: 1r Seminari Internacional: Barcelona 24-28 d'abril de 1989, Barcelona 1989, s. 30; tego samego zdania jest np. M. Charageat, Sztuka ogrodów, przeł. A. Morawińska, H. Pawlikowska, Warszawa 1978, s. 5-6.

${ }^{41}$ Notabene John D. Hunt wiąże rozwój badań nad ogrodami z zainteresowaniem kwestiami ekologicznymi i rozwijającą się „turystyką ogrodową”, dla której przyrodnicze aspekty ogrodów są niezmiernie ważne (Hunt, op. cit., s. 5).

42 Assunto, Il restauro dell'idea di giardino..., s. 32.

${ }^{43} \mathrm{G}$. Böhme, Znaczenie ogrodu angielskiego i jego teorii dla rozwoju ekologicznej estetyki przyrody, (w:) idem, Filozofia i estetyka przyrody $w$ dobie kryzysu środowiska naturalnego, przeł. J. Merecki, Warszawa 2002, s. 66-80; na ogrody - tyle że wschodnie - jako na 
Logika, estetyka i etyka ogrodu to zatem trzy działy filozofii ogrodu, ta zaś łącząc w sobie zarówno filozofię natury, jak i filozofię sztuki (techniki), w ostatecznym rozrachunku okazuje się filozofią ekologii, przez co należy rozumieć filozofię będącą namysłem nad miejscem człowieka w jego środowisku.

Filozofia ta - podobnie jak kontemplacja natury - nie ma przy tym charakteru jedynie refleksji, ponieważ ma także, a wręcz przede wszystkim wymiar czynny. Ogrodnictwo jest działaniem filozoficznym w tym sensie, że „uprawia” ono filozofię natury (jako sztuki) i filozofię sztuki (jako natury)44. W tym sensie, każdy, kto „żyje” w ogrodzie, czyli przebywa w nim, uprawia filozofię ogrodu czy też - jak przed chwilą zaznaczyliśmy - filozofię ekologii. Powracamy tym samym do kwestii esencji ogrodu.

Sposób, bowiem, w jaki uprawia się ogród, a zarazem w jaki, na przykład, się go zwiedza, nie jest dobrowolny - jest podyktowany istotą ogrodu, tzn. jego ideą. Nie do pomyślenia, dla Assunto, jest więc uprawianie ogrodu niczym przemysłowej plantacji i podobnie nie do pomyślenia jest, by jedyną przyjemnością płynącą z przebywania $\mathrm{w}$ ogrodzie była przyjemność np. fizyczna, związana z korzystnym oddziaływaniem natury na człowieka. Tak więc ogrodnictwo to:

[praktyki], których wymiar filozoficzny właśnie dostrzegliśmy (...). To bowiem, co właśnie z grubsza opisaliśmy, to zespół działań (mających swój początek w rolnictwie i murarstwie), których celem jest opieka nad pięknem ziemi i natury, sprzyjanie mu i ochranianie go na wszelkie sposoby, a co za tym idzie umacnianie szczęśliwego związku człowieka z ziemią, której jest synem i która go żywi, a także związku człowieka z naturą, do której należy jako istota żyjąca, tak jak należą do niej - jako istoty żyjące - biedronka siedmiokropka, biegacz złocisty, ropucha czy gekon. Kiedy mówię szczęśliwy związek, mam na myśli związek, który rodzi się razem z pełną zadziwienia kontemplacją $(. .)^{45}$.

Warto podkreślić, że w teorii Assunta to estetyka prowadzi do ekologii, a nie odwrotnie ${ }^{46}$. Assunto krytycznie bowiem odnosi się do ruchów zielonych przekonujących do przyjmowania nastawienia ekologicznego za pomocą argumentów mówiących o pożyteczności natury dla człowieka. Tego

przykłady harmonijnego współżycia z naturą patrzą także estetycy, np. A. Berleant, Nature and habitation in a Chinese Garden, (w:) idem, Aesthetics beyond the arts. New and recent essays, Farnham 2012, s. 131-145.

${ }^{44}$ Assunto, Il giardinaggio come operazione filosofica, s. 7-12.

45 Ibidem, s. 10; na zadziwienie jako jeden z elementów estetycznego doświadczania natury wskazuje także R.H. Hepburn, Wonder, (w:) idem, Wonder and Other Essays: Eight Studies in Aesthetics and Neigbouring Fields, Edinborough 1984), s. 9-35.

46 Zob. przyp. 8. 
rodzaju argumenty, jego zdaniem, będą zawsze słabsze niż argumenty dowodzące pożytków płynących $\mathrm{z}$ dominacji nad naturą. Z tej racji wszelka obrona ekologii musi sytuować się na płaszczyźnie estetyki. Naturę można przy tym chronić i naturą można się opiekować zarówno w skali lokalnej - tj. w skali ogrodu albo krajobrazu - jak i globalnej, jedynie wtedy, gdy będzie się miało na uwadze jej piękno, wtedy, gdy się to piękno na nowo odkryje i doceni.

W estetycznej przyjemności - pisze - jaką daje ogród (która na zasadzie dialektycznej zawiera w sobie korzyści dziś nazywane ekologicznymi oraz przyjemność odtwarzania życia) zaiste zdajemy sobie sprawę z faktu, że my i drzewa, my i trawy, kwiaty, ptaki oraz wszystkie zwierzątka mieszkające w ogrodzie jesteśmy ze sobą tożsami ${ }^{47}$.

W tym znaczeniu ekologia polega na traktowaniu świata właśnie jako ogrodu. Nie oznacza to, rzecz jasna, niewykorzystywania dóbr natury piękno samo w sobie jest bowiem użyteczne, a ponadto zawiera $\mathrm{w}$ sobie użyteczność.

Filozofia ogrodu zarysowuje więc wizję ekologii opartej na samoograniczającym się wykorzystywaniu natury i „estetyce opieki”, słowem na idei estetyki zrównoważonego rozwoju 48 :

(...) ogrodnictwo (...) uczy rolnictwo (w epoce uprzemysłowienia wystawione na pokusę uprawiania gospodarki drapieżnej i opartej na wyzysku), by szanowało ono integralność przyrody i by nie wykorzystywało jej ani nie niszczyło (chcąc wytwarzać produkty nadliczbowe i nie pasujące do pory roku ${ }^{49}$.

Filozofia ogrodu ma, koniec końców, cel jednak o wiele szerszy, zawarty w idei samego estetyzmu spekulatywnego. Jej wyrazem jest między innymi tak istotna, zdaniem Assunta, w czasach współczesnych, restauracja dawnych ogrodów. Restaurowanie ogrodów samo w sobie jest więc działaniem filozoficznym, ponieważ restaurując je, restaurujemy ideę ogrodu:

(...) restauracja natury, z jej najważniejszym aspektem - restauracją ogrodów, to nie tylko restauracja estetyczna: estetyka to bowiem wyraz logiki etyki. Estetyczna restauracja ogrodów jako restauracja sztuki jako natury, natury jako sztuki, pragnie wyrażać restaurację dokonywaną na gruncie teorii, tj. chce wyrażać przywrócenie prymatu Logosu nad utylitaryzmem, na gruncie filozofii zaś -

47 Assunto, Il giardino come filosofia della natura e della storia..., s. 14.

48 J.I. Nassauer, Messy Ecosystems, Orderly Frames, „Landscape Journals”, 14 (2), 1995: 161-170; eadem, Cultural sustainability. Aligning Aesthetics and Ecology, (w:) Nature, Aeshtetics and Environmentalism: from Beauty to Duty, ed. A. Carlson, S. Lintott, New York 2008, s. 363-379.

49 Assunto, Il giardinaggio come operazione filosofica, s. 11. 
przywrócenie metafizyki wbrew scjentyzmowi i utylitaryzmowi. Etyczna restauracja to $\mathrm{z}$ kolei przywrócenie kontemplacji jako fundamentu i ostatecznego kresu $\operatorname{praxis}^{50}$.

Dla Assunto zatem uzasadnienie konieczności troski o zachowane ogrody i restauracji ogrodów z przeszłości ma charakter metafizyczny, a nie historyczny czy społeczny. Tym bowiem, czego doświadcza człowiek w ogrodzie, są nie tylko wytwory określonych poetyk ogrodowych, ale także i przede wszystkim idea Ogrodu, w której zbiegają się estetyka (piękno), etyka (dobro) i logika (prawda), ustanawiając szczęśliwy związek ze światem.

\section{FILOZOFIA OGRODU - FILOZOFIA W OGRODZIE}

Zaproponowaną przez Assunta filozofię ogrodu można krytykować $\mathrm{z}$ rozmaitych stron, zwłaszcza mając $\mathrm{w}$ pamięci dorobek humanistyki spod znaku poststrukturalizmu czy dekonstrukcji. Można jej zarzucać utopijność i towarzyszącą jej klasowość - ogrody przeważnie są własnością uprzywilejowanych (którym notabene, państwo, zdaniem Assunto, powinno pomagać w ich utrzymaniu), a przekonanie, że również doświadczanie ogrodu spoza bramy czy spoza muru ma swoją wartość, uznawać za naiwne ${ }^{51}$. I podobnie za naiwne można uznać przywoływanie renesansowych leges horti regulujących zachowania w ogrodzie, tj. praw, dzięki którym wszyscy stawali się równi sobie i siebie nawzajem szanowali. Można też wskazywać na to, że Assunto ulega dobrze znanym mitom, np. mitowi radosnego, spokojnego, życia wiejskiego w zgodzie z naturą, który to mit może świadczyć o jego tradycjonalizmie: „dobra” wieś to wieś tradycyjna, zdaje się on bowiem powiadać. Również jego jednoznacznie negatywny stosunek do społeczeństwa masowego może być uznawany za przestarzały ${ }^{52}$.Wreszcie można by zarzucać, że czyni on określone metafizyczne założenia dotyczące kondycji współczesnego człowieka, który wyalienował się od natury, co nieuchronnie musi prowadzić do katastrofy tak kulturalnej, jak i ekologicznej. Przy okazji z kolei przyjmuje on romantyczne w duchu supozycje dotyczące natury, sztuki i relacji między

50 Idem, Il restauro dell'idea di giardino..., s. 32.

51 Takie jednak było np. założenie władz Londynu, które twierdziły, że choć do niektórych ogrodów wstęp mogą mieć jedynie właściciele, to jednak emanującą z nich aurą spokoju mogą cieszyć się wszyscy (D. Lowenthal, The English Landscape, „Geographical Review", vol. 54, 1964, nr 3, s. 331.

52 Wypada jednak zaznaczyć, że w latach 50. Assunto z dużą dozą optymizmu odnosił się do przemian społecznych i rozwoju gospodarczego we Włoszech (D. Luciani, Suivre le cheminement d'une pensée: les étapes d'un combat intellectuel, (w:) Retour au jardin, s. 172-185). 
nimi (istotnie, wzoruje się w tym m.in. na Kalliasie F. Schillera). Na domiar wszystkiego, nawet tam, gdzie pisze o etycznym podejściu do natury, o poczuciu wspólnoty z bytami nie-ludzkimi, Assunto ani na chwilę nie porzuca perspektywy antropocentrycznej.

$\mathrm{Z}$ tego wszystkiego Assunto zdawał sobie sprawę, będąc - jak wspomniano - świadom anachroniczności swej koncepcji. Z tego względu jego filozofia może się podobać, ale i drażnić. Nie może jednak ulegać wątpliwości, że jest ona dziełem osoby o głębokiej humanistycznej kulturze, która nie tylko interesowała się ogrodami z czysto intelektualnego punktu widzenia, ale także była estetycznie wrażliwa na ich uroki. Assunto nie był jednak wyłącznie filozofem ogrodów, estetykiem zajmującym się krajobrazami. Był także historykiem, dobrze znającym zarówno historyczne ogrody, jak również literaturę $\mathrm{z}$ nimi związaną. W pewnym sensie był nawet przede wszystkim historykiem, ponieważ to dzięki lekturze tekstów i znajomości konkretnych realizacji mógł odpowiedzieć na pytanie „czym jest ogród?”. Tak więc, jeśli kogoś nie przekonuje proponowana przez niego filozofia, to i tak lektura jego tekstów dostarcza ogromnej dawki historycznych wiadomości o tym, jak na przestrzeni wieków myślano o ogrodach i jak je doświadczano (a przynajmniej o tym, jak opisywano tego rodzaju doświadczenie). To zaś zbliża jego myśl do kulturowej historii ogrodów. Co więcej, Assunto - uwzględniając perspektywę historyczną - opisuje ( $\mathrm{w}$ opinii piszącego te słowa $\mathrm{w}$ sposób przekonujący) kwestię relacji między sztuką i naturą, tę drugą traktując - odmiennie niż wspomniane badania kulturowe, ale także większość historyków jako coś więcej aniżeli „medium” sztuki ogrodowej, w którym kultura odciska swoje znaczenia. Tym samym, analizuje on to, co stanowi nie tylko sedno ogrodnictwa, ale także to, co powoduje, że ogrody - jak zauważa J.D. Hunt - są tak wyjątkowe wśród sztuk: najpełniej bowiem odzwierciedlają one kondycję człowieka, łączącego w sobie kulturę i naturę 53.

Jak wspomniano we wstępie, filozofia ogrodu Assunta to zjawisko osobne. Na uwagę przy tym zasługuje to, jak wiele wątków, podejmowanych przez innych badaczy, poruszył Assunto niezależnie od nich. Co więcej, jego koncepcja filozoficzna wytrzymuje próbę przełożenia jej na inne języki i osadzenia w innych, nierzadko bardziej współczesnych ujęciach. To zaś oznacza, że w ujęciu włoskiego filozofa aparat pojęciowy sprzed 200 lat nie stracił na aktualności (co z kolei oznacza, że współczesna refleksja nie wykroczyła poza ówczesny horyzont, przynajmniej dotychczas).

53 J.D. Hunt, Gardens: historical overview, (w:) Encyclopedia of Aesthetics, vol. 2, ed. M. Kelly, Oxford 1998, s. 271-274. 
O aktualności filozofii Rosaria Assunta świadczy również fakt, że łączy się ją z takimi dokumentami jak wspominana już Karta Florencka, będąca całkowicie współczesnym i praktycznym wyrazem teoretycznego ujęcia Assunta i w której czytamy:

Ogród historyczny (...) posiada wartość ogólnospołeczną. (...) jest kompozycją architektoniczną, której materiał podstawowy stanowi roślinność, a więc materiał żywy podlegający zniszczeniu i odrodzeniu. Jego wygląd jest wynikiem stałej równowagi pomiędzy rozwojem i zanikaniem natury zgodnie z rytmem przemijania pór roku, a wolą artysty i umiejętnym działaniem mającym na celu jego utrwalenie. (...) Jako wyraz ścisłego związku pomiędzy cywilizacją i naturą, przeznaczony do rozmyślań i marzeń, ogród jest kosmicznym obrazem świata, „rajem” w etymologicznym znaczeniu tego słowa, lecz równocześnie stanowi on znamię danej kultury, danego stylu, danej epoki, czasem oryginalności jego twórcy ${ }^{54}$.

\section{THE AESTHETICS, ETHICS, AND LOGIC OF THE GARDEN. ROSARIO ASSUNTO'S PHILOSOPHY}

\section{Summary}

The essay offers a philosophical interpretation of the concept of the garden according to the contemporary Italian aesthetician Rosario Assunto (1915-1994). Assunto systematically developed a philosophical theory focused on the question of the identity of the garden. He was interested in the "idea of the Garden" which, in his opinion, determined historical gardens both at the ontological and epistemological level. He defined the garden in terms of a happy connection of man and nature, based on the aesthetic contemplation of beauty, characteristic of all the gardens regardless of historical differences among them. According to Assunto, gardens are places which combine together aesthetics, ethics, and logic. This combination determines the unique identity of the garden which takes various forms, depending on the individual poetics of their makers, socio-historical realities, taste, and the correspondent ideas of nature. Assunto's starting points are thus historical versions of the garden, descriptive literature, and German philosophy of the turn of the $19^{\text {th }}$ century. For the Italian philosopher, gardens have not only historical and artistic, but also ecological aspects, so that they should be protected and restored. Assunto's theory is a unique proposal which anticipates today's reflection on the topic of gardens, but seems much more satisfactory than many contemporary approaches (A. Berleant, M. Miller, S. Ross).

54 IFLA-ICOMOS, Karta florencka (1981), za: www.nid.pl [dostęp: 25.06.2015]. 